\title{
Sensory evaluation, nutritional quality and antinutritional factors of traditionally co-fermented cereals/cowpea mixtures as infant complementary food
}

\author{
*Oyarekua, M. A. \\ Department of Biological Sciences, Faculty of Science \\ University Science and Technology, (USTI), Ifaki-Ekiti, Nigeria
}

\begin{abstract}
Grains of winnowed cereals and cowpea were weighed in ratio 70:30 w/w (cereal: cowpea) and given to four mothers randomly selected from Well-Baby Clinics. Mothers prepared the mixtures using traditional method of cereal ogi processing. Chemical compositions of obtained mixtures were determined using official standard methods. Proanthocyanidins was by direct sample extraction and absorbance read at 550nm. Total phenol estimation was determined using the Folin \& Cioclteu method. Organoleptic properties were determined using 9-point Hedonic scale method. Values of crude protein (\%) were comparable in all samples sorghum/cowpea ogi had 11.2; millet/cowpea ogi 10.6 and maize/cowpea ogi 11.0 respectively. Dry matter contents (\%) in all samples were comparable. Crude fibre content was higher in millet/cowpea than maize/cowpea and sorghum/cowpea. Phosphorus, magnesium, iron and copper contents (ppm) were higher in millet/cowpea than sorghum/cowpea and maize/cowpea. Values of zinc were comparable in maize/cowpea (1280) and sorghum/cowpea (1150) both of which were significantly higher $(p<0.05)$ than millet/cowpea of 554 . Antinutritional factors $(\mathrm{ppm})$ were reduced by cofermentations in all samples. Co-fermentation did not improve the crude protein content, reduced significantly $(p<0.05)$ the mineral contents except zinc and manganese in millet/cowpea. Maize/cowpea ogi was preferred to sorghum/cowpea and millet/cowpea ogi in organoleptic properties.
\end{abstract}

Keywords: Cereals, legumes, organoleptic- properties, nutritional quality

\section{INTRODUCTION}

The purpose and type of processing applied in preparing complementary foods for infants should be for separation and purification of the edible parts of raw material and most importantly it should also improve the nutritional qualities by enrichment and inactivation of the anti-nutritional factors. The low socio-economic status mothers are not adequately knowledgeable about the available nutrients and the anti-nutritional factors in the raw materials (Omoruyi et al; 2007, Wang et al; 1997). So gruels prepared from fermented cereals are of high viscosity and low in energy density; therefore, they are not potentially nutritious enough to be used as complementary foods. It is therefore desirable to propose a processing method in which cereals and cowpeas can be jointly processed to reduce labour, cost, energy and loss of nutrients that could arise from separate processing of cereals and cowpeas.

Many efforts had been made to improve the nutritive value of cereal by supplementation with legumes:
Bressani and Scrimshaw (1961) reported that cowpea-maize mixture provided the highest quality of protein at ratio 45 parts maize to 15 parts cowpea and 27parts maize to 21parts cowpea. Asaye (2004) observed that as cowpea level in the blends increased, the percentage fat decreased and percentage protein increased. Akinyele and Fasaye (1988), reported improvement in nutritional quality in sorghum/ cowpea mixture, Lopez et al. (2005), recommended that sorghum, common bean tempeh could be used as supplementary food. Balaubramania and Viswanathan (2007) used fermentation process to improve the nutritive value of rice-legume blend. They observed that the most acceptable products were those containing the rice flour dehulled legume in a 70:30 ratio and had the best overall organoleptic acceptability.

The overload of work usually carried out by low socio-economic status mothers makes complementary food preparation time inadequate; also there is financial constraint in obtaining baby formula. There is therefore need to formulate an easy 
Agric. Biol. J. N. Am., 2010, 1(5): 950-956

modified traditional process using locally available staple raw materials that might yield products of high nutritive quality.

Various works had been done on the organoleptic properties of supplemented cereals with legume mixtures. Not much had been done on the effect of co-fermentation on the organoleptic, nutritional and antinutritional properties of co-fermented cereals/legume mixture. This work investigated this aspect.

\section{MATERIALS AND METHODS}

Materials: Grains of maize (Zea mays), sorghum (Sorghum vulgare) and cowpea (Vigna unguiculata) were obtained from a local market in Ibadan, southwestern part of Nigeria.

\section{Sensory Evaluation}

Sample preparation: Cereal/cowpea mixtures were prepared in ration $70: 30 \mathrm{w} / \mathrm{w}$. The mixture was soaked in tepid water for three days after which each mixture was wet milled, sieved and allowed to stand in steeping water for 24 hours. The supernatant was decanted leaving slurry. The slurry of each mixture was dewatered. A ratio of about 1:4 (slurry: water) was mixed and boiled for about 15 minutes. The boiled gruel was allowed to cool to about $45^{\circ} \mathrm{C}$. Gruel of each sample was served to trained panelists of fifty. Each panelist was made to assess each product based on the 9-point Hedonic scale (9=like very much, 1=dislike extremely) and the attributes to be tested are: * appearance-colour. *texturesmoothness. * softness-soft. *taste-sweetness- too bitter. *mouth feel *aroma. *general acceptability.

Proximate composition and Minerals: Procedure: According to AOAC (2005).

Each sample was triplicated and analyzed for chemical proximate composition: dry matter, protein, fat, ash and mineral composition were determined according to OAAC (1990).carbohydrate was obtained by difference. Crude fibre and digestible carbohydrate were not differentiated. $\mathrm{Fe}, \mathrm{Cu}, \mathrm{Zn}, \mathrm{Mg}$, $\mathrm{K}, \mathrm{Mn}$ and $\mathrm{Na}, \mathrm{Ca}$ were determined by atomic absorption spectrophotometery. (GBC Scientific Equipment Pty. Ltd.

One gram of sample was weighed into each crucible and transferred into Muffle Furnace pre-set at 530oC for 120 minutes. The crucibles were cooled and weighed; this was done in triplicates. The percentage ash was calculated. Phosphorus was determined using spectrophotometer at 430nm.
Crude Protein was determined according to microKjeldahl Procedure AOAC (2005).

Lipid content was determined according to AOAC (2005).

\section{Antinutritional Factors}

\section{Estimation of Proanthocyanidins}

Procedure: Half gram of sample was weighed into a $20 \mathrm{ml}$ test tubes, $10 \mathrm{ml}$ of $5 \% \mathrm{HCl}$-butanol was added. Contents were vortexed and heated in water bath at $100^{\circ} \mathrm{C}$ for two and a half hours. The content of each tube was filtered into $25 \mathrm{ml}$ volumetric flask using a glass micro fiber filter paper (Whatman GF/A) and made up to volume with $5 \% \mathrm{HCL}$-Butanol reagent. Dilutions of cyaniding chloride standard solution $(100 \mathrm{ug} / \mathrm{ml})$ and unheated samples were subjected to the same experimental procedure as samples. Proanthocyanidin content was expressed as cyanidin chloride equivalent and determined by using a calibration curve of the absorbance at $550 \mathrm{~nm}$, against the concentrations of standard solutions. The absorbance read at $550 \mathrm{~nm}$ was subtracted from values obtained from unheated samples so as to get the true value of proanthocyanidin content.

Estimation of total phenols: Standard method AOAC (2005) in which total phenol is which is expressed as chlorogenic acid equivalent, was used for the estimation of total phenols.

Statistical analysis: Comparison results between samples among triplicates readings of experimental were treated using the ANOVA test (analysis of variance) with a probability level of $(p>0.05)$ using computer program (StaSoft Inc., 1999)

\section{RESULTS AND DISCUSSION}

Table 1 shows the chemical proximate composition, ph and total titrable acidity(TTA). of traditionally cofermented millet/cowpea, sorghum/cowpea maize/cowpea and their unfermented counterparts. Unfermented mixtures had higher dry matter than their co-fermented counterparts. The co-fermented samples had significant reduction $(p>0.05)$ in $\mathrm{pH}$ values and higher TTA values. Co-fermentation reduced crude protein in co-fermented millet/cowpea from $10.6 \%$ to $13.6 \% ; 13.8 \%$ in co-fermented sorghum/cowpea to 11.25 while co-fermentation did not affect the crude protein value in co-fermented maize/cowpea (13.4\%) and $13.4 \%$ in unfermented maize/cowpea. This finding was contrary to the report of Uche et al., (2008), who reported that supplementation before fermentation (co- 
fermentation) improved protein, fat ash and but agreed their finding that the fermentation improved some minerals like sodium, iron and zinc. There was increase in the crude fiber values of co-fermented mixture compared their unfermented mixtures; but there was reduction in crude fiber value of cofermented maize/cowpea compare to unfermented maize/cowpea mixture. The lipid content appeared higher in unfermented mixtures than co-fermented mixtures.

Table 1: Comparison of proximate chemical composition (\%) between traditionally prepared millet/cowpea, sorghum/cowpea maize/cowpea ogi and their unfermented counterparts

\begin{tabular}{|l|l|l|l|l|l|l|}
\hline Sample & Dry matter & pH & TTA & Crude protein & Crude fibre & Lipid content \\
\hline TMC & ${ }^{\mathrm{bcd}} 87.6 \pm 0.050$ & ${ }^{\mathrm{b}} 4.1 \pm 0.05$ & ${ }^{\mathrm{abcd}} .18 \pm 0.04$ & $10.6 \pm 0.19$ & ${ }^{\mathrm{abcd}} 4.2 \pm 0.24$ & ${ }^{\mathrm{b}} 2.7 \pm 0.07$ \\
\hline UMC & ${ }^{\mathrm{de}} 88.8 \pm 0.01$ & ${ }^{\mathrm{f}} 6.3 \pm 0.01$ & ${ }^{\mathrm{abc}} .13 \pm 0.00$ & $13.6 \pm 0.27$ & ${ }^{\mathrm{abc}} 4.0 \pm 0.45$ & ${ }^{\mathrm{cd}} 3.7 \pm 0.21$ \\
\hline TSC & ${ }^{\mathrm{de}} 88.6 \pm 0.24$ & ${ }^{\mathrm{a}} 3.9 \pm 0.03$ & ${ }^{\mathrm{d}} .30 \pm 0.04$ & $11.2 \pm 0.34$ & ${ }^{\mathrm{a}} 3.0 \pm 0.35$ & $2.6 \pm 0.19$ \\
\hline USC & ${ }^{\mathrm{ab}} 88.1 \pm 0.02$ & ${ }^{\mathrm{f}} 6.5 \pm 0.04$ & ${ }^{\mathrm{a}} .08 \pm 0.02$ & $13.8 \pm 0.10$ & ${ }^{\mathrm{abc}} 4.9 \pm 0.33$ & $2.9 \pm 0.04$ \\
\hline MZ/C & ${ }^{\mathrm{de}} 88.7 \pm 0.11$ & ${ }^{\mathrm{c}} 4.5 \pm 0.12$ & ${ }^{\mathrm{a}} .08 \pm 0.00$ & $11.1 \pm 0.26$ & ${ }^{\mathrm{ab}} 3.4 \pm 0.29$ & ${ }^{\mathrm{bc}} 3.1 \pm 0.13$ \\
\hline MZ/C & ${ }^{\mathrm{e}} 89.2 \pm 0.04$ & ${ }^{\mathrm{f}} 6.4 \pm 0.01$ & ${ }^{\mathrm{ab}} .10 \pm 0.00$ & $13.4 \pm 0.34$ & ${ }^{\mathrm{abc}} 4.3 \pm 0.01$ & ${ }^{\mathrm{e}} 4.8 \pm 0.20$ \\
\hline
\end{tabular}

Values in the column followed by different superscripts are significantly different $(p<0.05)$.

*Mean of three replicates.

Key:

$\mathrm{pH}=$ hydrogen ion concentration

TTA $=$ Total titrable acidity

TMC $=$ Traditionally co-fermented millet/cowpea

UMC = Unfermented millet/cowpea

TSC $=$ Traditionally co-fermented sorghum/cowpea

USC = Unfermented sorghum/cowpea mixture

TMZ/C = Traditionally co-fermented maize/cowpea

$\mathrm{UMZ} / \mathrm{C}=$ Unfermented maize/cowpea mixture

Table 2 Protein energy malnutrition is increasingly being regarded not as deficiency of protein and energy only, but of some nutritionally important

Table 2: Mineral Composition (ppm) of Traditionally prepared co-fermented ogi samples and their unfermented counterparts

\begin{tabular}{|c|c|c|c|c|c|c|c|c|c|}
\hline Sample & $\mathbf{P}$ & $\mathrm{Na}$ & $\mathrm{K}$ & $\mathrm{Ca}$ & Mg & $\mathrm{Fe}$ & $\mathrm{Cu}$ & $\mathrm{Zn}$ & Mn \\
\hline TMC & ${ }^{\mathrm{a}} 160 \pm 0.07$ & ${ }^{\mathrm{ab}} 520+3.01$ & g510+15.89 & ${ }^{\mathrm{D}} 2970 \pm$ & c1520 \pm 5.00 & $\mathrm{~d} 1690 \pm 55.00$ & cde60 0.02 & de554+15.07 & c51+0.02 \\
\hline UMC & ${ }^{c} 1300 \pm 0.0$ & ${ }^{\mathrm{ab}} 200+0.28$ & ${ }^{9} 6400 \pm$ & ${ }^{\mathrm{a}} 4045 \pm$ & c1337+5.00 & $\mathrm{e} 792 \pm 21.65$ & $\mathrm{~b} 42 \pm 0.01$ & ${ }^{a} 339 \pm 2.50$ & c81+0.03 \\
\hline TSC & ${ }^{\mathrm{D}} 130 \pm 0.06$ & ${ }^{\mathrm{a}} 440 \pm 0.73$ & ${ }^{\mathrm{D}} 7100 \pm$ & g1414 \pm 5.00 & h1780 \pm 55.00 & e785+21.65 & ${ }^{\mathrm{b}} 48+0.01$ & b1159+20.00 & cde53+0.02 \\
\hline USC & $\mathrm{d} 1800 \pm 35.0$ & ${ }^{\mathrm{ab}} 200 \pm 0.28$ & ${ }^{\mathrm{h}} 7510 \pm$ & ${ }^{\mathrm{e}} 4910 \pm$ & ${ }^{\mathrm{h}} 2176 \pm$ & ${ }^{\mathrm{ab}} 606 \pm 0.01$ & ${ }^{\mathrm{bc}} 6100 \pm$ & $936 \pm$ & $\mathrm{cd} 206 \pm 5.89$ \\
\hline TMZC & ${ }^{b} 140 \pm 0.05$ & $710 \pm 12.8$ & ${ }^{\mathrm{b}} 6770 \pm$ & c1550 \pm 5.0 & c1530 \pm 5.0 & g860+24.30 & e310_2.50 & b1280 \pm 20.00 & cde53+0.02 \\
\hline UTMZC & ${ }^{\mathrm{cd}} 13800 \pm 12.5$ & b1130 \pm 20.0 & c1360 \pm 5.0 & '3136+ & ${ }^{\dagger} 1003 \pm 20.00$ & d1885+53.00 & g587+15.07 & ${ }^{\circ} 85 \pm 0.03$ & e425 412.93 \\
\hline
\end{tabular}

Values in the column followed by different superscripts are significantly different $(p<0.05)$.

Each value is a mean of three replicates.

KEY:

TMC = Traditionally co-fermented millet/cowpea

UMC = Unfermented millet/cowpea

TSC= Traditionally co-fermented sorghum/cowpea

USC = Unfermented sorghum/cowpea mixture

$\mathrm{TMZ} / \mathrm{C}=$ Traditionally co-fermented maize/cowpea

$\mathrm{UMZ} / \mathrm{C}=$ Unfermented maize/cowpea mixture minerals which are components of key enzymes. The body uses mineral ions as electrolytes to help regulate, the distribution, composition and acidity of its fluids.

The phosphorus content ranged between 130ppm for co-fermented sorghum/cowpea and 1800ppm for unfermented sorghum/cowpea. Values for cofermented millet/cowpea 160, unfermented millet/cowpea 1300, co-fermented maize/cowpea 140 and unfermented maize/cowpea of $13800 \mathrm{ppm}$ were significantly $(P>0.05)$ different. 
Phosphorus which is present in cells and blood as phosphate ions, reacts with fats and carbohydrates to release energy, it combines with calcium to give rigidity to bones and to maintain blood neutrality(Adeyeye and Faleye 2004). The phosphorus values were reduced by fermentation in all samples and the calcium/phosphorus ratio was not widened by fermentation this is contrary to the finding of Brooks (2009) that fermentation release phosphorus bound by phytate in fermented liquid feeds. In this study, the consumption of all cofermented samples in this work can easily meet the body's phosphorus requirement.

For sodium content, co- fermentation generally increased sodium content of all samples. Highest percent increase of 710 was observed in cofermented maize/cowpea, while unfermented maize/cowpea had the highest value of 1130 . Cofermentation led to significant ( $00>0.5)$ reduction in the potassium content of co-fermented millet/cowpea (510) compare to its unfermented analogue of 6400 , co-fermented sorghum/cowpea (710), its unfermented counterpart was 75100 and cofermented maize/cowpea (677)compared with unfermented sample of 131300 .

Modification of the traditional process had a significant effect (increase) on the sodium contents of the three co-fermented ogi mixtures. Sodium is the major cathion of fluids in the body cells. The sodium values of both samples in this work was 3-4 fold lower than recommended value of sodium needs from complementary foods for ages 6-23months.

The potassium values were consistently higher in unfermented samples than the co-fermented analogues, is an intracellular cation bound to protein and sodium and it influences osmotic pressure and contributes to normal $\mathrm{pH}$ equilibrium. Allowance of Sodium/potassium ratio of 0.60 is recommended this means consumption of $40 \%$ more potassium than sodium to balance blood electrolyte. In this study, the ratio in co-fermented sorghum/cowpea (0.61) is comparable to recommended ratio, while the value of millet/cowpea is significantly $(p<0.05)$ higher than recommended ratio. However, the ratio was significantly $(p>0.05)$ lower in co-fermented maize/cowpea and in unfermented mixtures of sorghum/cowpea, millet/cowpea and maize/cowpea.

Calcium is an important mineral for bone and teeth formation (Smith 2005) as well as body structure and in blood clotting. Its deficiency can lead to rickets in infant and children). The co-fermented samples in this work have calcium significantly $(p>0.05)$ lower than $52500 \mathrm{ppm}$ required in complementary foods for 6-12 months old and 35000ppm/day for 1223 months old per day. The value of Calcium in all samples of this work will adequately meet the calcium needs from complementary foods (WHO/UNU.98) for ages9-11months (based on daily consumption of $250 \mathrm{ml} / \mathrm{d}$ ); and in excess of the required calcium content needed for 11-23months (based on daily consumption of $750 \mathrm{ml} / \mathrm{d}$ ).

For Iron, fermentation led to increase in iron content where increase was associated with ferrous content in co-fermented samples, millet/cowpea (1690), sorghum/cowpea (785), maize/cowpea (16.04). Fe levels which were generally higher in co-fermented samples than unfermented samples is in agreement with earlier report that fermentation increase iron availability by a factor of 2-6. Iron intake is inadequate during 6 months to 4 years of age because of low iron content of milk and rapid growth rate in infants and children. Only $10 \%$ of all dietary iron is absorbed through the small intestine into the blood. Infants need iron to meet the need for red blood cells synthesis and growth. The amounts of iron required daily are 10000 - 15000ppm for children. Iron-deficiency anemia affects young children it impairs physical and cognitive development and immune response to disease. Deficiency of iron can be mild when iron store is low in the body, can be severe when it is low in the blood levels of heamoglobin. Symptoms of iron deficiency include fatigue, depressed growth and neuropsychomotor development. In this study iron content is higher in co-fermented millet/cowpea and sorghum/cowpea than their unfermented analogues, while that of unfermented maize/cowpea is significantly $(p<0.05)$ higher than its co-fermented analogue. Excess iron can lead to iron poisoning in children. (Adeyeye and Faleye 2004 ).

There was no significant difference were observed in copper and zinc contents.

Zinc is a limiting factor in the growth of severely malnourished infants. The deficiency can also reduce the immune response, loss of appetite and growth retardation Zinc deficient is prevalent in infants in developing countries because the diets are low in animal products and high in phytates. Diarrhoea is also an important cause of intestinal zinc loss (WHO/NUT/98). The value of zinc in this study which ranged between 17-14000ppm/d may not lead to significant increase in length of 3-5year olds within 6 
months as reported by Rosalldo et al (1997). In this study, the zinc values were higher in co-fermented millet/cowpea, maize/cowpea than their unfermented analogues and higher in unfermented sorghum/cowpea mixture than the co-fermented counterpart. Excess zinc may decrease the amount of high-density lipoprotein (HDL) circulating in the blood leading to risk of heart disease. Excess zinc also decreases the function of immune system.

Copper is part of several important enzymes needed for the manufacture of haemoglobin and the red blood cells in bone marrow. It helps in the integrity of connective tissue, bone, nerves and cardiovascular systems, immune system and blood clotting systems. The copper contents in this study were higher in cofermented millet/cowpea than its unfermented samples but lower in co-fermented sorghum/cowpea and maize /cowpea than their unfermented analogues.

Manganese in microgram $(\mu \mathrm{g})$, unfermented sorghum/cowpea had the highest content (2.06), while unfermented millet/cowpea had the lowest content (0.81). Values obtained for co-fermented sorghum/cowpea and maize/cowpea were comparable and differed significantly from their unfermented counterparts. Manganese helps in skeletal development and proper functioning of the brain and spinal cord. Deficiency can lead to defective growth abnormalities, central nervous systems and disturbances in the way the body handles fats. The values of manganese in this work were lower in co-fermented mixtures than unfermented mixtures and were comparable to the recommended daily requirement for 11-23months old.(WHO/NUT.98).

A similar pattern of reduction by fermentation was followed for magnesium except in sorghum/cowpea where unfermented sample had a higher level. Magnesium level however was higher in sorghum/cowpea ogi than millet/cowpea and maize/cowpea. Magnesium and values in both cofermented samples were significantly $(p>0.05)$ too low to meet the recommended daily allowance for 6 23 months.

Magnessium is needed for more than 300 different enzymes systems in the body. It is important in formation of Adenosine trio phosphate, storage of carbohydrates, fats and protein, in nerve and muscle activity. This observation is consistent with earlier reports of Soloma and Owolawashe (2007).
Values of most minerals were higher in unfermented samples than their co-fermented analogues except in sodium, iron, magnesium and zinc. The reduction in the mineral contents in all traditionally co-fermented mixtures may be due to leaching of the soluble inorganic salt during steeping, fermentation time (4 days) and disposal of the steep water prior to milling. The losses may be attributed to loss during sieving and dewatering in the process.

Ash content was low and comparable in both cofermented and unfermented samples. Cofermentation process especially sieving and dewatering stages might have reduced the ash content of both samples.

Some minerals especially when taken in large amount can result in abnormally high levels $n$ the blood for example; high levels of calcium in the blood can decease normal kidney functions.

\section{Sensory Evaluation}

Table 3 shows the sensory evaluation results of maize/cowpea, sorghum/cowpea and millet/cowpea ogi. In the color rating; maize/cowpea ogi had (7.5) which was higher than that of millet/cowpea (6.5), sorghum/cowpea (4.6). While the value of texture was also higher in maize/cowpea ogi (7.6) than millet/cowpea (6.4), and sorghum/cowpea (5.4). The values of the taste were: maize/cowpea ogi (8.04) millet/cowpea (6.4) and sorghum/cowpea (5.2). Also the values of the aroma 7.2 in maize/cowpea ogi and significantly $(p<0.05)$ different from that of millet/cowpea (5.6) and sorghum/cowpea (5.7). The general acceptability score was significantly $(p<0.05)$ higher in maize/cowpea than millet/cowpea and sorghum/cowpea.

Table 3: Sensory evaluation between gruels made from co-fermented maize/cowpea, sorghum/cowpea and millet/cowpea (70: $30 \mathrm{w} / \mathrm{w}$ ) ogi

\begin{tabular}{|c|c|c|c|}
\hline $\begin{array}{l}\text { Sensory } \\
\text { attributes }\end{array}$ & $\mathrm{XYU}$ & TST & WVZ \\
\hline Colour & $7.5^{a}$ & $6.5^{b}$ & $4.6^{C}$ \\
\hline Taste & $8.0^{a}$ & $6.4^{\mathrm{b}}$ & $5.2^{c}$ \\
\hline Texture & $7.6^{a}$ & $6.4^{\mathrm{b}}$ & $5.4^{c}$ \\
\hline Aroma & $7.2^{\mathrm{a}}$ & $5.6^{c}$ & $5.7^{\mathrm{C}}$ \\
\hline $\begin{array}{l}\text { General } \\
\text { Acceptability }\end{array}$ & $8.5^{a}$ & $7.0^{b}$ & $5.8^{C}$ \\
\hline $\begin{array}{l}\text { KEY: } \\
\text { XYU = maize/cc } \\
\text { WVZ = sorghum } \\
\text { TST = millet } / \text { so }\end{array}$ & & & \\
\hline
\end{tabular}


Sensory evaluation is referred to as subjective measurement since it is subject to human errors. The other evaluations are called objective measurements, which involve physical, chemical and microbiological evaluations. The results of these objective measurements must be correlated with the results of sensory evaluation so that acceptability of the food by the ultimate consumer can be correctly ascertained. For sensory evaluation results to be meaningful, they must be interpreted statistically. All results of products were statistically analyzed at $1 \%$ level by analysis of Variance (ANOVA). Color/appearance: the uncooked flour and paste of maize/cowpea had a pale whitish color while that of sorghum/cowpea ogi was pale brownish and millet/cowpea was light reddish. However the cooked gruel of the three products showed the similar score in terms of colour.

The millet/cowpea gruel had a rough texture in compared to sorghum/cowpea and maize/cowpea ogi. Sorghum/cowpea and millet/cowpea had more radish taste than maize/cowpea ogi probably due to varietal differences. There was sourer flavor in millet/cowpea compared to sorghum/cowpea, which also had a sourer flavour than maize/cowpea ogi. At $45^{\circ} \mathrm{C}$, millet/cowpea ogi solidified faster than sorghum/cowpea and maize/cowpea ogi. Maize/cowpea ogi was preferred to sorghum/cowpea and millet/cowpea. Omueti, Jaiyeola, Otegbayo, Ajomale and Afolabi (2009) reported that fortified maize with soyflour, groundnut and crayfish for prowena was more acceptable than unfortified yellow maize in terms of taste, flovour and texture but not in colour.

The difference between the rating of the three products might be mainly because maize ogi is the familiar product to the panelists this might have played an integral part in the panelist's response to maize/cowpea ogi which is the new product. Therefore the judgment of the new product was largely based on comparison with maize ogi that the consumers had been used to. If maize/cowpea ogi is cooked longer than 10 minutes, the taste might be acceptable. However the rating of maize/cowpea is still higher than any of the three, despite being a new product.

\section{Antinutritional Factors:}

Table 4. There was no significant difference between fermented and unfermented samples in proanthcyanidin content this finding is contrary to the finding of ljarotimi and Esho (2009) who reported that fermentation lowedr antinutritional factors. There was also no significant difference between maize/cowpea (5ppm), unfermented maize/cowpea(3ppm) and between sorghum/cowpea (9ppm) and unfermented sorghum/cowpea(6ppm) and also between sorghum/cowpea and unfermented sorghum/cowpea. The values obtained for unfermented millet/cowpea(55ppm) and cofermented millet/cowpea(66ppm) were higher than in other samples. For total phenol- there was no significant difference associated with each of the cofermented samples with their respective unfermented analogues.

Table 4 : Antinutritional factors (ppm) in fermented cereals, and co-fermented cereals/cowpea ogi.

\begin{tabular}{|l|c|c|}
\hline Sample & Proanthocyanidin & Total phenol \\
\hline TMC & ${ }^{\mathrm{a}} 66$ & ${ }^{\mathrm{e}} 13$ \\
\hline UMC & ${ }^{\mathrm{b}} 55$ & ${ }^{\mathrm{a}} \mathrm{b} 17$ \\
\hline TSC & ${ }^{\mathrm{c}} 9.0$ & ${ }^{\mathrm{a}} \mathrm{b} 15$ \\
\hline USC & ${ }^{\mathrm{a}} 6.0$ & ${ }^{\mathrm{a}} 10$ \\
\hline TMZC & ${ }^{\mathrm{a}} 5.0$ & ${ }^{\mathrm{a}} 23$ \\
\hline UMZC & ${ }^{\mathrm{a}} 3.0$ & ${ }^{\mathrm{a}} 12$ \\
\hline
\end{tabular}

Values in the column followed by different superscripts are significantly different $(p<0.05)$.

Each value is a mean of three replicates.

KEY:

TMC $=$ Traditionally co-fermented millet/cowpea

UMC $=$ Unfermented millet/cowpea

TSC $=$ Traditionally co-fermented sorghum/cowpea

USC $=$ Unfermented sorghum/cowpea mixture

$\mathrm{TMZ} / \mathrm{C}=$ Traditionally co-fermented maize/cowpea

$\mathrm{UMZ} / \mathrm{C}=$ Unfermented maize/cowpea mixture.

Co-fermentation led to significant reduction in proanthocyanidin. This present study also recorded little or no change in the total phenol of co-fermented mixture compared with unfermented mixture. This is in agreement with the findings of Gibson et al; 2006 , Agte et al; (1997).

Phenolic compounds have been reported to have high inhibitory effect on iron absorption (Glahn et al 2002) as well as reduction in protein and carbohydrate digestibility (Emine Nur Herken, 2005). Their presence in foods in high quantities is therefore not desirable. The levels reported in this work are low and may therefore not be of a major nutritional importance. The decrease in proanthocyanidin (tannins) is desirable in view of its ability to adversely affect protein digestibility. However, nowadays, there is considerable interest in the antioxidant activity of these compounds (tannins) and their potential health benefits, especially in the prevention of cancer and 
cardiovascular disease in adults (Vijaypupam et al 2003).

CONCLUSION: Co-fermentation reduced the crude protein content compared to unfermented mixture this might have effect on protein quality in terms of amino acids. Co-fermentation increased mineral contents of millet/cowpea ogi and also significantly affected the organoleptic properties of cereals/cowpea ogi. Maize/cowpea ogi was preferred to sorghum/cowpea and millet/cowpea ogi. Proanthocyanidin and total phenol contents were slightly reduced. Cofermentation did not reduce dry matter, crude fiber and lipid content in all the samples. However cofermentation reduced crude fiber in sorghum/cowpea and millet/cowpea when compared with unfermented mixture. Co-fermentation significantly $(p<0.05)$ reduced lipid content when compared with unfermented mixtures.

\section{ACKNOWLEDGEMENT:}

We wish to thank Centre for Research and Deveopment (IRD) Montepellier, France for funding part of this work and Federal Polytechnic, Ado-Ekiti, Nigeria, for the use of their facilities for this work.

\section{REFRENCES:}

Adeyeye El, and Faleye FJ (2004). Mineral Components for Health from Animal sources. Pakistan Journal of Science and Industrial Research. 47 (6): 471-477.

Akinyele IO and Fasaye OA (1988). Supplementation with (Vigna unguiculata) in the Traditional manufacture of 'ogi'. Journal of Food Science. 53:1750-1755

AOAC( Association of Official Analytical Chemists) (2005). Official Methods of Analysis of the Association of Analytical Chemists International, 18th ed. Gathersburg, MD U.S.A Official methods 2005.08

Agte VV, Gokhale M K and Chiplonkar S A (1997). Effect of natural fermentation on in-vitro zinc bioavailability in creal-legume mixture. International Journal of Food Science and Technology 32(1): 29-32.

Asaye OA(2004). Improving Processing Technology and Nutritional Composition of Nigerian Traditional Breakfast Gruel from Corn and Okra. J. Agic. \& Food Information. 6 (1). The Hartworth Press Inc

Balaubramanian S and viswanathan RJ( 2007). Properties of Indli batter during its fermentation time. DOI: 10.1111/j1745-4549.2007.00104x

Emine Nur Herken, Senol Ibanoglu Mehmet, D.Oner, Neermiu Bilicli and Sali Guzel (2005). Effect of Storage on Phytic acid Content, Total antioxidant capacity and organoleptic properties of macaronienriched with cowpea flour. J.of Fd. Eng. 78 (1):366372.
Glahn RP, Wortley GM , South PK and Miller DD (2002). Inhibition of iron uptake by Phytic Acid, Tannic Acid and Z-C12 Studies Using in -vitro Digestion/CaCo2Cell Model. J. Agric. Food Chem. 50: 390-395.

Gibson RS Perlas L and Hotz C (2006). Improving the Bioavailability of Nutrients in plant food at the household level. Proc. of Not. Society. 65.160-168.

ljarotimi OS and Esho TR (2009). Composition and antinutritional status of fermented, germinated and roasted bambara groundnut seeds (Vina Subterranea) British Food Journal. 3 (4):376-386. Emerald Group Publishing Limited.

Lopez SD, Giraldez FJ, Dhanoa MS, Dijstra J and France J (2005). Assessment of Nutritive Value of Cereals and Legumes straus based on Chemical Ccomposition and In-vitro digestibility. DOI:101002/jsfa.2136

Omoruyi FO, Ashworth L and Asemote HN (2007). Nutrion and Food Science 37(1):8-15.ISSN:0034-6659. Emalrald Group Publishing.

Omueti O, Jaiyeola O, Otegbayo B, Ajomale $\mathrm{K}$ and Afolabi O (2009). Development and Quality Evaluation of Low Cost High Protein Weaning Foods Types:Browena and Propalm from Soybean (Glycine max) Groundnut(Arachis hypogeal) and Crayfish(Macrobrachim spp.). British Fd.Journal. 3(2):196-204.

Rosaldo JLP, Lopez H M and Allen LH (1997). Zinc supplementation reduced morbidity, but neither zinc nor iron supplementation affected growth or body composition of Mexican preschoolers. Am. J. Clin. Nutr. 65:452-461

Smith, J V (2005.) Geochemical Influences on Life Origins and Evolution.-Mineralogical Society of America. 1 (3):151-156

Soloma M and Owolaswasshe H (2007). Amino Acid, Fatty Acid and Mineral Composition in a legume Cereal Based complementary food Blend used in Jos Nigeria. Internet J. of Nutr. and Wellness. 14(1) ISSN 1937-8297.

Vijaypuspam T Krishna Kumari, Menon Raghunatta Rao and Anthony GM (2003). A Quinalitative Assessment of Nutritional Knowledge Levels and Dietary Intake of School Children in Hyderbad. Public Health Nutrition 6.683-688.

Wang N, Lewis MJ, Breman, J G, Westby and A (1997). Effect of processing methods on nutrients and antinutritional factors in cowpea. _Food Chemistry. 58 (1-2): 59-68.

World Health Organization(WHO/NUT.98) (1998). Complimentary Feeding of Infants and Young Children. Report of A Technical Consultation Supported by WHO/UNICEF, University of California/Davies abd ORSTOM. WHO.NUT/96-9 